\title{
КОНЦЕПТУАЛИЗАЦИЈА БРАКА И СРОДНИХ ПОЈМОВА У СРПСКОМ ЈЕЗИКУ
}

\begin{abstract}
Предмет рада је концептуализација појмова из лексичко-семантичког поља брак код студената Филозофског факултета у Нишу. Циљ је да се открије ментална слика о браку и сродним појмовима из перспективе младих путем испитивања метафоризације издвојених појмова. У истраживању је примењен асоцијативни метод. Као инструмент истраживања коришћен је асоцијативни тест у коме су ексцерпирани примери дати као стимулуси. Резултати теста представљени су квантитативно и квалитативно. Анализа показује да се код већине појмова појављују срећа, љубав, венчане, породица и поштоваюе као реакције испитаника. Издвојене су и доминантне концептуалне метафоре у грађи: БРАК ЈЕ ПУТОВАҢЕ, ПОРОДИЧНИ ДОМ ЈЕ ГНЕЗДО, БРАЧНИ ДРУГ ЈЕ ОСЛОНАЦ, БУРМА ЈЕ ОБРУЧ, МАТИЧАР ЈЕ СУДИЈА, НОВИ ЧЛАН ПОРОДИЦЕ ЈЕ ЖИВОТИҢА. Испитивање показује опречне ставове младих према браку, а као чешће истичу се позитивне реакције.
\end{abstract}

Кључне речи: вербалне асоцијације, концептуализација, брак, појмовна метафора, српски језик

\section{1. Увод}

Разноврсност људских ставова и утицаји културе допринели су да лексика често зависи од контекста употребе, при чему се утврђује њен прави смисао. У овом раду анализирају се лексеме које су у вези са браком и свим обичајима који га прате. Лексема брак се одређује као апстрактна именица, те се њено значење може схватити вишеструко. У речницима се брак уобичајено дефинише само као „законита заједница мушкарца и жене основана ради породичног живота" (RSJ 2007). Међутим, говорници српског језика брак и све што га прати доживљавају на различите начине, а појмови у вези са браком подстичу на бројне асоцијације. Стога се у раду испитују концепти које људски ум формира приликом сусрета

1 dj.sunjevaric-15757@filfak.ni.ac.rs. 
са овом апстрактном лексиком.

Предмет истраживања чини концептуализација ${ }^{2}$ појмова из лексичко-семантичког поља брак код студената Филозофског факултета у Нишу. У истраживању се примењује асоцијативни метод, а као инструмент истраживања користи се асоцијативни тест који чини 40 речи-дражи или стимулуса из домена брака. Представљање добијених резултата асоцијативног теста врши се квантитативном и квалитативном методом. Циљ је да се сагледа ментална слика младих о браку и сродним појмовима путем испитивања метафоризације. Очекује се да ће се увидом у ментални лексикон нишке студентске популације показати да окружење има утицаја на ставове који се формирају.

У испитивању ексцерпираних примера примењује се концептуална анализа као део когнитивне лингвистике, будући да је она „најприкладнија за проучавање апстрактне лексике” (DRAGIĆEVIĆ 2010a: 89). Драгићевић наводи основне механизме концептуализације апстрактних појмова: појмовна метафора, појмовна метонимија и типични сценариju. Појмовне метафоре утемељили су Лејкоф и Џонсон (1980). Од појаве књиге Metaphors We Live By метафора се посматра и као механизам мишљења, диференцирајући се тако од традиционалне поетске метафоре. Појмовна метафора подразумева пресликавање појмова из двају домена на основу њихове сличности, што наводи на „opštu formulu pojmovne metafore koja glasi X je Y” (STEVANOVIĆ 2015: 120). Према томе, појмови из једног домена који су апстрактни у језику разумеју се помоћу појмова из другог домена, а они су конкретни и блиски људском искуству, те се лако повезују са нечим апстрактним. Кевечеш (2002) пак напомиње да то пресликавање није потпуно, већ се само поједини аспекти апстрактног појма схватају помоћу конкретног, а остали су прикривени и не улазе у подручје интересовања. Према типу концептуализације усвојена је подела на структурне, оријентационе и онтолошке метафоре (LEJKOF, DŽONSON 1980). Све врсте појмовних метафора указују на сличност двају домена. Преостали механизми концептуализације односе се на један домен. На постулатима утврђеног теоријског оквира настојаћемо приступити примерима из грађе и добијеним подацима из асоцијативног теста.

2 Концептуализација подразумева „образовање појмова на основу човековог физичког, чулног, емоционалног и интелектуалног искуства о свету који га окружује” (KLIKOVAC 2004: 9; DRAGIĆEVIĆ 2010а: 90). Ристић (1999: 134) концептуализацију одређује као процес који се заснива на „логичком и сублогичком повезивању апстрактних и конкретних садржаја на основу заједничких општих својстава који се експлицирају у предикативним спојевима или се имплицитно изводе из спојева другог типа”. 
1.1. Досадашња истраживања

У новије време (метафоричка) концептуализација представља веома често коришћену појаву која се истражује из више аспеката. Д. Вељковић Станковић (2018) и С. Новокмет (2013) испитивали су ову појаву код појма бол у српском језику. Аутори прецизно указују на представу људи о осећању бола и подједнако разматрају физички и душевни бол. Полазећи од типичног сценарија бола као „угрожавања/рањавања људског бића од стране непријатеља” (VELJKOVIĆ STANKOVIĆ 2018: 161), ауторка концепт бола проналази у глаголима (нпр. жигати, пробадати, umpeц,aтu), чиме је дала додатни аспект сагледавања концептуализације. Новокмет (2013: 417) у примерима из електронских извора примећује да се бол „најтипичније може налазити у човеку [...] али се исто тако може налазити споља". Из те анализе проистичу најфреквентније концептуалне метафоре: БОЛ ЈЕ САДРЖАНИ ОБЈЕКАТ, МАТЕРИЈА И БОЛ ЈЕ СИЛА, ТЕРЕТ, ЖИВО БИЋЕ, ПРОТИВНИК, ВЛАДАР. ${ }^{3}$ Аутор добро увиђа да је бол најчешће доживљен као активни ентитет. До сличних изворних домена долази и Слијепчевић (2012) испитујући концептуализацију појма савест (БИЋЕ, МАТЕРИЈА, ПРЕДМЕТ). Након анализе издвојених примера, ауторка закључује да у српској култури постоји противречно доживљавање савести, што се огледа у следећем: „пожељна је активна савест, која може бити и мирна, али је човек негативно доживљава онда када она није била активна већ се неким његовим лошим поступком активирала" (SLIJEPČEVIĆ 2012: 73). Примери из корпуса тог рада показују да је концептуализација појмова неодвојива од културе у којој се ти појмови користе, јер „свака култура образује специфичан оквир унутар којег се интерпретирају одабрани спољни знаци реалности" (DRAGIĆEVIĆ 2010b: 11). Повезивање са културом на прави начин доприноси бољој анализи у истраживањима концептуализације.

Концептуализација појмова може обухватати разноврсна подручја истраживања, међу која убрајамо и наставни процес (JANJIĆ 2017; JANJIĆ, ČUTURA 2012). У истраживању кључних појмова наставног процеса (JANJIĆ 2017) примењен је асоцијативни тест. Одговори испитаника показују тежњу ка савременим токовима наставе и позитиван став о модернизацији наставе. Концептуализација тих појмова у методичким уџбеницима указује на „богатство асоцијативног поимања савремених наставних атрибута" (JANJIĆ 2017: 98). На тај начин формирани концепти у свести испитаника и изворни домени у уџбеницима потпуније осветљавају методичке појмове.

Неретко се у анализи именица примењује асоцијативни метод

3 Уобичајена је пракса да се концептуалне метафоре пишу малим верзалом, те ћемо се тога придржавати и у овом раду. 
(BROĆIĆ 2016; DRAGIĆEVIĆ 2010b). Наведене ауторке бавиле су се концептуализацијом емоција (љутња, туга, страх, понос и сл.). Броћић (2016) користи асоцијативни метод како би утврдила елементе типичног сценарија и типичног субјекта испитане емоције. Анализом добијених асоцијација, ауторка издваја најфреквентније типове поноса и мајку као типичног носиоца ове емоције (BROĆIĆ 2016). Драгићевић (2010b) примењује више типова асоцијативног теста како би се добила што објективнија слика концептуализације емоција. Један од њих је одговарање на стимулусе асоцијацијама, а по том узору осмишљен је тест за наше истраживање. Добијени резултати зависе од концепта теста и мотивације испитаника, али се предност ове методе огледа у томе што је објективнија, јер се закључци ослањају на асоцијације више људи (DRAGIĆEVIĆ 2010b: 170). Пошто асоцијативни метод значајно доприноси расветљавању менталне слике циљне групе, биће примењен и у овом раду.

Досадашња истраживања концептуализације бавила су се вишеструким испитивањем ове појаве на примерима из бројних лексичко-семантичких поља. Лексема брак је у прегледаној литератури посматрана као изворни домен приликом структурисања појма (хотелског) пословағъа у идиомима енглеског језика (MILOŠEVIĆ 2017). Појам брак у контексту тог истраживања упућује на „proces udruživanja i spajanja različitih kompanija" (MILOŠEVIĆ 2017: 125). То је илустровано појмовним метафораМа ПОСЛОВАҢЕ ЈЕ ЉУБАВНА ИГРА, СПАЈАҢЕ КОМПАНИЈА ЈЕ БРАК И КОМПАНИЈЕ СУ ЉУБАВНИЦИ. Овим истраживањем аутор јасно показује семантичко богаћење пословног (енглеског) језика. И у српском језику брак учествује у процесу концептуализације, што ћемо испитати у нашем раду из више углова.

У другом делу рада биће разматрани сви ексцерпирани примери, као и резултати добијени на основу асоцијативног теста. Треће поглавље посвећено је метафоризацији кључних појмова из грађе у контексту примера из електронског корпуса. Закључке свих испитивања даћемо у последњем поглављу.

\section{2. Испитивање грађе}

Испитивање грађе се састоји из три дела. У првом делу се групишу и анализирају лексеме ексцерпиране из речника (RSJ 2007), у другом се те лексеме испитују помоћу асоцијативног теста, а у трећем делу се дају концептуалне метафоре на основу примера из корпуса (SrWaC).

За потребе истраживања ексцерпирана је грађа која обухвата лексему брак и све лексеме из семантичког поља брак. Укупно је ексцерпирано 40 именица или именичких синтагми. ${ }^{4}$ Издвојени појмови могу 4 Подаци из Асоиијативног речника српскога језика нису од значаја за ово истражива- 
се поделити у две лексичко-семантичке групе према типу референта: прва група примера упућује на особе, док су у другој групи примери који се односе на појмове из неживог света.

На основу ексцерпиране грађе запажа се да више примера упућује на особе: брачни друг, брачни пар, девер, деца, жена, зет, кум, матичар, млада, младении, младожень, муж, партнер, родитељь, сватови, сведок, свекар, свекрва, снаха, стари сват, супружник, таст и ташта. Поред назива за особе које склапају брак, у грађу су уврштени називи чланова нове породице, коју млада и младожења стичу ступањем у брак. Међу лексемама су и називи особа које су присутне на венчању. Наведене лексеме доживљавају се на основу улоге коју именовани људи имају. Ове речи најчешће асоцирају на конкретне особе које познајемо из непосредног окружења. Стога се претпоставља да окружење има великог утицаја на ставове које људи формирају, па особине појединаца они стереотипно везују за сваку особу која се налази у тој улози, што се може рефлектовати и у одговорима које испитаници буду давали.

Друга група примера именује апстрактне процесе и обичаје везане за брак: венчаюе, годишюииа брака, женидба, просидба, прстеноваюе, развод, свадба, спајање и удадба. Процеси исказани наведеним лексемама односе се на почетак или крај брака, као и на друге важне догађаје. Њих прате бројни традиционални обичаји, те су у зависности од културе народа и краја у коме он живи, различите и асоцијације, јер „сваки језик на свој начин рашчлањава свет" (DRAGIĆEVIĆ 2010b: 12).

Преостали примери из грађе су разноврсни: брачна заједница, породииа, дом, кумство; бурма, прстен; тубав, тајна. Њихово значење секундарно упућује на брак. Наведени појмови добијени су асоцијативним путем. Бурму или прстен носи свако ко је у браку, љубав је основа за брак, а брак се одређује и као света тајна. Развијају се породични и кумовски односи стварајући једну заједницу, а брак се може представити и као нови дом. Везе међу ексцерпираним појмовима, као и могуће реакције на њих показаће асоцијативни тест.

\section{1. Асоцијативни тест}

Све ексцерпиране лексеме наведене су у асоцијативном тесту као речи-дражи. Тест се састоји од 40 различитих појмова из домена брака датих азбучним редом. Задатак испитаника био је да на њих одговоре барем једном речју или синтагмом која им падне на памет, а било је могуће написати и више асоцијација. Испитано је 130 студената филилошких департмана на Филозофском факултету у Нишу старости од 19 до 28 го-

ње јер се у њему брак и већина других лексема из корпуса не налазе као стимулуси, а и циљ је сагледати концептуализацију искључиво код нишких студената. 
дина, а сви испитаници су у упитнику исказали сагласност за учешће у истраживању. Доминантна је група испитаника женског пола (70\%).

На лексему брак су сви испитаници имали неку асоцијацију. У испитивању је добијено 55 различитих реакција, а најфреквентније су љубав (47), заједница (18), породииа (16), деца (12), муж (7), срећа (6), обавеза (6) и жена (5). ${ }^{5}$ Ове речи казују да се брак углавном доживљава као породично окружење. Неколико студената брак схвата као нешто што намеће обавезе и велику одговорност. Међутим, брак се може концептуализовати и веома негативно, као затворен и страшан простор из којег се тешко излази, на шта указују реакције затвор, гроб и пакао. Асоцијације на брак са негативним значењем показују и примери досада, обруч, примитивизам и сл. Међу асоцијацијама уочавају се и два придева: тежак и дивљи ${ }^{6}$. Осим појмова деца, муж и жена, које је навело више испитаника, и други називи за људе су такође честе реакције на стимулус брак: родитељь (3), супружници, млада и партнер. Сви испитаници су имали барем једну асоцијацију на брак, а многи њихови одговори налазе се на листи стимулуса у асоцијативном тесту. Један испитаник наводи тренутак завршетка брака - развод. На основу разноврсности и великог броја асоцијација види се да брак још увек није чврсто утемељен у когнитивном асоцијативном систему.

Најфреквентнија асоцијација на брак је љубав. Лексема љубав је стимулус са најраспршенијим реакцијама. Скоро стотину различитих речи и конструкција доведено је у везу са осећањем љубави, а по фреквентности се издвајају срећа (27), срие (9), породииа (9), поверене (7) и осећағе (7). Међу асоцијацијама су бројна друга, слична осећања, као и особине људи који исказују љубав. Метафора љУБАВ ЈЕ СРЦЕ потиче од везивања свих људских осећања за срце, од којих је љубав најизраженија. Пошто се љубав доминантно осећа према одређеним особама, није необично што један део асоцијација именује људе: деца (3), мајка (2), мој дечко, родители, брат, сестра и сл. Као реакције коришћене су и личне заменице (он, она). Бројни су и придеви којима испитаници одређују льбав: права, јака, најважнија, неограничена, истинска и др. Готово да нема асоцијација на стимулус љубав са негативним значењем. Сви испитаници навели су своју асоцијацију, али је само срећа забележена у више од десет одговора.

Појам (брачна) заједница, који је на другом месту по фреквент-

5 Уз анализиране стимулусе наводимо до 10 најфреквентнијих реакција (са 5 и више одговора), а број у загради означава укупан број испитаника који је навео тај појам као реакцију на задати стимулус.

6 Израз дивљи брак уобичајен је у језику, а означава 'везу, заједничко живљење мушкарца и жене без законске потврде' (RSJ 2007). Тиме се именује заједница супротна брачној. 
ности појављивања, одређен је помоћу 66 појмова. Код овог стимулуса као најфреквентније реакције испитаних студената издвојиле су се породица (16), муж ижена (13), деца (10), льубав (9), папир (8) и партнери (7). Поред очекиваних асоцијација којима се указује на породично окружење, именица папир је овде фреквентнија него међу реакцијама на стимулус брак. Њоме се истиче званичност брачне заједнице и њена обавезност. Овакву заједницу скоро десетина испитаника доживљава као нешто наметнуто и ограничено: формалност (3), друштвена конвенција, ограниченост, ужас, манак слободе и лудило. Тиме се може наслутити известан отпор младих према брачној заједници. Међутим, у одговорима доминирају позитивне реакције на такву заједницу: срећа (3), слога (3), поверење (3), разумеване (2), склад (2), хармонија, лепота и др.

На стимулус породица одреаговано је на више начина: дом (25), тьубав (18), срећа (14), заједница (12), сигурност (10) и топлина (9). Студенти су лексему породица одредили користећи укупно 59 различитих појмова. Прве асоцијације испитаника представљају кључне појмове који се најчешће повезују са породицом. Од назива људи јављају се чланови уже породице (мама, тата, деца), а осим именица, асоцијације чине и придеви (велика, важна, чврста, битна). У одговорима на овај стимулус налазе се само позитивне реакције, што показује да породица за свакога представља нешто најлепше и најзначајније у животу (светиюа, благо, сврха постојаға, смисао живота и сл.).

Именица деца као стимулус добила је 65 различитих асоцијација, а најчешће су срећа (35), льубав (22), породииа (9), обавеза (8), богатство (6), мала (6) и смех (5). Најфреквентнију реакцију дало је око $30 \%$ испитаника, те се не може са сигурношћу тврдити да постоји утврђена асоцијативна веза међу појмовима срећа и деца. Поред придева мала, јављају се и волена, весела и сл. Већина испитаника доживљава децу као млада бића, повезујући их са игром, васпитањем и образовањем. Поједини тек виде у њима нову генерацију људи (потомство, продужетак врсте, будућност, наследници). Ретке су асоцијације на деиу са негативном семантиком (напаст, неваспитане).

Лексеме муж и жена убрајају се у фреквентне асоцијације на брак. Најчешће реакције на лексему муж су: жена (16), супруг (12), љуббав (10), партнер (9), подрика (9), ослонаи (7), отаи (7) и сигурност (6). Приметне су речи из исте лексичко-семантичке групе као и стимулус (антоним жена и синоним супруг). Остале мање фреквентне асоцијације описују мужа наводећи уобичајене карактеристике (снага, храброст, озбиљан, вредан и др.). Именица жена је семантички богатија. За разлику од примера муж са 57 асоцијација, за ову именицу дато је 75 различитих одговора. Најфреквентније асоцијације испитаника су мајка (22), супруга (12), 
снага (10), льубав (8), лепота (7) и стуб (7). Истакнуте су особине жене као лепшег пола, али и њена важна улога у породици. И овде се јавља синоним (супруга) као друга најчешћа реакција. Антоним муж био је међу асоцијацијама код 4 испитаника. Бројни су придеви које испитаници наводе у одговорима: добра (2), уредна, способна, јака, одана, вредна и др.

О венчању се говори на различите начине, а према одговорима испитаника најчешће се ова реч користи у позитивном контексту: свадба (24), ирква (15), венчаница (15), прослава (15), церемонија (9), бела боја (7) и срећа (6). Док је једна група испитаника повезала венчање са догађајем, други су истакли препознатљиве детаље попут венчанице, беле боје и сл. Тиме су утврдили везу конкретних кључних симбола са апстрактним догађајем. Особе које су испитаници наводили као реакције на венчағе су матичар (3), млада (2), младожень и сватови. Од датих асоцијација (68) неколико има негативну семантику: бацане пара (2), глупост, кич, велики трошак, претеривағе, скупо и сл. Ипак, чешће су асоцијације у којима се огледа благонаклон став према овој церемонији: свечаност (2), провод, незаборавно, кафана, торта и др. На основу одговора, приметно је да испитанике читав процес венчања асоцира на конкретне особе које у томе учествују, различита места и појмове, као и на осећања која људе преплављују у том тренутку (радост, љьббав).

Одговор развод јавља се међу асоцијацијама на брак, а брак је најчешћа реакција на развод као стимулус. На то је вероватно утицао фреквентан синтагматски спој развод брака. Асоцијације на развод су брак (17), туга (9), неслога (8), суд (7), несрећа (7), растанак (6), свађа (6), крај (6) и нестанак поверена/почтоваға/льубави (6). Као асоцијације навођени су и најчешћи узроци који доводе до развода: превара (2), несугласище, лаж, насиље и др. Већина појмова које наводе испитаници има негативну семантику и указује на тужан тренутак: бол (3), непријатност, плач, катастрофа и сл. Међутим, уочавају се и супротни ставови: слобода (3), боле него лош брак (2), живот иде дате (2), нова шанса, крај мукама, олакшағе, спас и сл. У оваквим одговорима види се да неколико испитаника доживљава развод као избављење од проблема и тешкоћа.

Именица прстен понавља се у одговорима испитаника на стимулус брак. Међу реакцијама на прстен јављају се следећи појмови: веридба (17), дијамант (13), симбол (12), бурма (12), накит (9), злато (8), веренички (6), прст (6), рука (6) и венчағе (5). Од укупно 52 различите реакције на прстен, већи број одговора одређује његов изглед, својства, као и функцију. Најфреквентнија асоцијација именује догађај на коме се двоје људи пре брака симболично везује у заједницу. Са негативним значењем издваја се метафора ПРСТЕН ЈЕ ОБРуч, што упућује на стегу и затвореност. Идентичан број реакција (55), као и слични појмови налазе се код 
лексеме бурма. Асоцијација коју наводи највише испитаника је прстен (39), а након ње следе венчане (19), симбол (10), злато (8), брак (5) и кум (5). Више је негативних реакција на бурму него на прстен (обруч, престанак слободе, лании, омча и сл.), јер лексема прстен има општије значење.

Анализа резултата добијених путем асоцијативног теста показала је да испитаници углавном имају сличне реакције на појмове који означавају људе, а засновани су на култури и њиховом личном искуству. Асоцијације испитаника које се понављају код више примера из ове групе су лубав, срећа, поштоване, подршка, поверене, сигурност и ослонаи. Сви наведени појмови појављују се као реакције на стимулусе брачни друг, родитель и супружник, а потом следе партнер и породица са једним појмом мање. По пет наведених појмова налази се уз стимулусе муж и macm, док је уз брачни пар и свекрва по четири. Поред издвојених појмова, у одговорима се често упућује на неки други назив за човека. Они који именују чланове нове породице одређени су лексемом за сродство: девер - брат (69); зет - (ћеркин/сестрин) муж/супруг (20); свекар - (мужевлев) отаи (46), деда (8); свекрва - (мужевљева) мајка (40), баба (6); снаха - (синовъева/братовљева) жена/супруга (24); таст - (женин) отаи, (46), деда (5); ташта - (женина) мајка (45), баба (4). Наведене лексеме сродства код ових именица из грађе представљају прву, најфреквентнију асоцијацију испитаника.

Примери из друге групе, који именују догађаје у вези са браком, такође се одређују уз помоћ неколико заједничких појмова: срећа, прослава, свечаност, иеремонија, чин и обичај. Све ове асоцијације испитаници су навели код појмова венчање, женидба, просидба и прстеновағе, док се код именице свадба јављају четири асоцијације, а код осталих и мање.

Испитани појмови показују бројност и разноврсност асоцијација. Најфреквентнија асоцијација на основу одговора испитаника је брат (69), а дата је за стимулус девер. Именица венчаница је прва реакција на стимулус млада, а друга је по фреквентности у грађи (53), док је, по истом принципу, одело асоцијација на младожену (48). Остале реакције које је навело више од трећине испитаних студената су КУМ ЈЕ ПРИЈАТЕљ (49), БРАК ЈЕ ЉУБАВ (47), СВЕКАР ЈЕ ОТАЦ (46), ТАСТ ЈЕ ОТАЦ (46), ТАШТА ЈЕ МАЈКА (45), ПОБРАТИМ ЈЕ ПРИЈАТЕљ (45) И СВАДБА ЈЕ ВЕСЕљЕ (44). С обЗИРОМ на то да се ови појмови понављају у одговорима, приметна је њихова ближа веза са стимулусима у когнитивном систему.

3. Метафоризација појмова из грађе

Представљањем резултата асоцијативног теста, уочени су могући начини концептуализације појмова из грађе. Метафоризација се уочава и код појмова који именују људе, али и догађаје у вези са браком. На 
подељена мишљења испитаника указују позитивни и негативни метафорички преноси. Пошто се брак и други сродни појмови из грађе узимају као циљни (апстрактни) домен који треба објаснити, у овом поглављу је нагласак на изворним доменима на које упућују испитаници. Концептуалне метафоре добијене путем асоцијативног теста биће илустроване употребом у контексту из Српског мрежног корпуса (SrWaC).

\section{1. Метафора ПУТОВАњА}

Појам брак се може структурисати помоћу домена путовања. БРАК ЈЕ ПУТОВАњЕ (пр. 1) представља концептуалну метафору добијену на основу више реакција. Догађаји приликом склапања брака чине полазну тачку тог путовања (ЖЕНИДБА/УДАДБА ЈЕ ПОЛАЗАК НА ПУТ). Оно без чега се не може на том путу је љубав, што се концептуализује на исти начин: ЉУБАВ ЈЕ ПУТОВАњЕ. Главне станице на брачном путу јесу годишњице брака, па и овај појам испитаници одређују у домену путовања. Учесници тог путовања су људи који склапају брак: МУЖ ЈЕ ПУТНИК, ЖЕНА ЈЕ ПУТНИК ИЛИ БРАЧНИ ДРУГ ЈЕ САПУТНИК, ПАРТНЕР ЈЕ САПУТНИК, СУПРУЖНИК ЈЕ САПУТНИК (пр. 2). Један број испитаника ово путовање види као борбу, те се особе које учествују у њој одређују као саборци: МУж, ПАРТНЕР, БРАЧНИ ДРУГ ЈЕ САБОРАЦ. Појам развод одређен је као крај путовања (в. пр. 3). Добијене асоцијације на појмове у вези са браком одредиле су кључне тачке у концептуализацији брака као путовања, где свадбене церемоније представљају припрему и одлазак на пут, а људи путнике.

(1) Te tri kafane podjednako smatram mestima na kojima smo se nas dvoje upoznali i utabali stazu za brak koji traje već duže od tri i po decenije. (blog. blic.rs);

(2) Ubrzo je došla vojska, pa ženidba. Svetlana je i danas Milošev verni saputnik. I u dobru, i u zlu. (glas-srbije.co.rs);

(3) U velikoj sam neprilici, brak mi je u fazi raspadanja i uskoro stižem do razvoda. (magicnazona.rs).

\section{2. Метафора ГНЕЗДА}

Стимулуси дом и породица подстакли су испитанике да окружење брачног пара упореде са гнездом. Формирање гнезда почиње након склапања брака. Метафора дОМ ЈЕ ГНЕЗДО има позитивну семантику јер се тиме наглашава сигурност и безбрижност људи (в. пр. 4). Муж и жена, односно младенци у контексту примера 5 метафорички су представљени као голупчићи, што је у вези са метафором ГНЕЗДА као куће и породице. Сем тога, дом се концептуализује и као још један леп и пријатан простор: ДОМ ЈЕ ОАЗА (пр. 6). Појмом оаза наглашавају се мир и хармонија који 
владају у брачној заједници. За разлику од изворног домена путовања, који је структурисао читав брачни процес укључујући и људе, домен гнезда везује се за простор у коме брачни пар живи.

(4) Mnoge žene smatraju da su ulaskom u brak završile jednu od najvažnijih životnih misija i da je sada vreme da predahnu od svih devojačkih problema, te da se ušuškaju u sigurnost koju nosi bračno gnezdo. (blog.nasasvadba.rs);

(5) Koliko su golupčići srećni govore osmesi na njihovim licima. (smedia. rs);

(6) Ugostio je četvoricu drugara iz benda u svojoj novoj oazi, gde od nedavno stanuje sa svojom suprugom. (prva.rs).

\section{3. Метафора СТУБА}

Лексема стуб метафорички се везује за породицу, и то искључиво за одређене њене чланове. Стуб је носећи елемент сваке конструкциje, па тако и брак, односно породица мора имати свог носиоца. Та улога припада неком члану породице, а од културе и других околности зависи ко ће то бити. Према добијеним одговорима у асоцијативном тесту, ЖЕНА ЈЕ СТУБ ПОРОДИЦЕ (пр. 7). Уобичајена природа жена је да брину о свему у кући, чиме заслужују своје носеће место. Насупрот овоме, за мушкарце се користи метафора гЛАВЕ, те се тако истиче њихова водећа улога у породици. Метафора СтуБА се доминантно користи за женске чланове породице.

(7) Uloga žena $u$ ekonomiji $i$ biznisu $u$ našoj zemlji nije na nivou na kome bi trebalo da bude, imajući u vidu da je porodica osnov našeg društva, a stub porodice je majka, žena. (pks.rs).

Слична овој лексеми је именица ослонаи. Наведена је као асоцијација код 9 назива за људе. Њоме се означавају људи који су апсолутно поуздани и на које увек можемо рачунати. Од назива за људе у грађи, ослонац могу представљати брачни друг, девер, жена, муж, партнер, породица, родитель , супружник и таст. Метафора чОВЕК ЈЕ ОСЛОНАЦ (пр. 8) доминантна је код појмова из прве лексичко-семантичке групе. Њоме се указује на блиске особе и брачне партнере.

(8) Njoj ne treba njegov novac već muž, muškarac koji je tu kad joj je teško, njen oslonac. (grlica.blog.rs).

\section{4. Метафора 3АТВОРА}

Током испитивања грађе уочено је да се брак концептуализује као затворени простор или нека институција. Негативни погледи на брак 
огледају се у следећим концептуалним метаформа: БРАК ЈЕ ЗАТВОР (пр. 9), ЖЕНИДБА ЈЕ ПУТ У ЗАТВОР, БУРМА ЈЕ ЛАНАЦ И МАТИЧАР ЈЕ СУДИЈА. ДаТЕ асоцијације на наведене појмове јасно исказују отпор према браку. Матичар је структурисан као судија који изриче пресуду и шаље младенце на издржавање казне (в. пр. 11). Брачни пар је представљен паром затвореника који су оковани ланцима (прстење), а слобода и решење мука следе им тек након развода брака. Једна од асоцијација на брак је и кавез, што је у блиској вези са овим појмовним доменом (в. пр. 10). Овакав ментални концепт јавља се код мањег броја испитаника.

(9) Tad nije bilo ovakvih otvorenih veza, morao si da se zatvoriš u brak. (anam.blog.rs);

(10) Mlada, zgodna, pametna, kajala se što je lakomisleno, slepo zaljubljena uletela u brak i to se na njoj primećivalo svakog dana. (dildo.rs);

(11) Matičar nas osuđuje na doživotnu. (alo.rs).

Слична овој је метафора ОБручА. Својства на која се жели указати пресликавањем појма обруч на појмове из грађе (бурма, прстен) јесу затвореност, стега, укалупљеност, недостатак слободе и сл. У корпусу се наилази на Појмовне метафоре БРАК ЈЕ ОБРУЧ и БУРМА/ПРСТЕН ЈЕ ОБРУЧ. Прстење које носе младенци, због свог кружног облика, асоцирало је мању групу испитаника на више сличних појмова: обруч, омча, ланци, окови и сл. Ради се о метафоричком преносу значења по облику:

(12) Oni se još osećaju previše mladim da bi uplovili u bračne vode i sebi nametnuli okove. (krstarica.com).

\section{5. Метафора ЖивОтИњЕ}

И називи животиња могу се користити у концептуализацији људи. Такве речи најчешће имају негативни призвук. Испитаници су поједине људе из грађе повезали са животињама: ЗЕТ ЈЕ МАГАРАЦ (пр. 14), МЛАДОЖЕЊА ЈЕ МАГАРАЦ, СВЕКРВА ЈЕ ЗМИЈА/АЖДАЈА (Пр. 13), ТАШТА ЈЕ ЗМИЈА и сл. Када се за мушког члана породице употреби назив магараи, тада се жели увредити његова интелигенција ${ }^{7}$ или истаћи да је то особа која се увек највише терети. Родитељи мужа и жене се концептуализују као опасне животиње које узнемиравају и нападају људе. Међу асоцијацијама на појам ташта среће се и ђаво као оличење зла и непријатељства. Будући да се у грађи срећу и позитивни ставови о овим особама, јасно је да асоцијација зависи од конкретног појединца кога познаје испитаник или је у вези са стереотипним представама у народу:

7 Лексема магараи, се приликом именовања људи углавном користи у значењу 'умно ограничен, глуп човек, глупак' (RSJ 2007). 
(13) Ta aždaja je sve činila od početka kako bi se osećala kao neko ko nije vredan njenog sina. (stil.kurir.rs);

(14) Nakon što sam završila slagalicu, ćerka me je slikala pored nje, dok je onaj njen magarac za to vreme sve uništio. (blic.rs).

\section{4. Закључак}

Појмови у вези са браком испитивани су асоцијативним тестом на узорку од 130 студената. За сваки појам из грађе забележено је више реакција: најмање је 34 (млада), а највише 96 (лубав). Ексцерпирана грађа је подељена у две групе примера, од којих се једна односи на особе, а друга на догађаје и остале апстрактне појмове из домена брака. У овим групама уочене су фреквентне асоцијације које се понављају код свих појмова: у првој групи су срећа, льубав, поштоваюе, подрика и сл., а у другој срећа, прослава, свечаност, дом и сл. Именица срећа представља најфреквентнију асоцијацију у грађи: наведена је код 29 појмова, односно представља реакцију на 70\% примера из корпуса. Најближа асоцијативна веза уочена је између појмова девер и брат (53\%). Лексеме млада и венчаница доведене су у везу у чак $41 \%$ одговора.

На основу добијених резултата испитивања препознају се и позитивни и негативни ставови младих у концептуализацији брака и сродних појмова. Једино се породица одређује свим асоцијацијама са позитивном семантиком. У анализи су издвојене структурне метафоре на које указују одговори испитаника. Позитивни ставови огледају се у појмовНИМ МеТафОРаМа БРАК ЈЕ ПУТОВАњЕ, ИНСТИТУЦИЈА, ДОМ; БРАЧНИ ДРУГ ЈЕ САПУТНИК, САБОРАЦ; ПАРТНЕР ЈЕ ОСЛОНАЦ, СТУБ, ГЛАВА; МЛАДЕНЦИ СУ ГОЛУПЧИЋИ; ДОМ ЈЕ ГНЕЗДО, ОАЗА и др. ОваквИ концептИ домИнирају у резултатима асоцијативног теста. Ипак, вођени другачијим искуством из свог окружења, постоје и испитаници који брак и сродне појмове доживљавају веома негативно. То се препознаје у метафорама БРАК ЈЕ ЗАТВОР, ГРОБ, ПАКАО; БУРМА ЈЕ ОБРУЧ, ЛАНАЦ, ОМЧА, ОКОВ; МАТИЧАР ЈЕ СУДИЈА; НОВИ ЧЛАН ПОРОДИЦЕ ЈЕ ЖИВОТИЬА И ДР.

За разлику од досадашњих истраживања концептуализације, у овом раду је представљен концепт брака као циљног домена, а испитивање је вршено и тестирањем савремених говорника и на основу електронског корпуса издвајањем концептуалних метафора. Реакције испитаника одражавају везу са њиховим породичним искуством и стеченим ставовима у најближем окружењу. Асоцијације показују да је доминантан ментални концепт брака код нишких студената позитиван. Приметно је да не постоји јака асоцијативна веза лексема из грађе са сродним појмовима. Стога, испитана лексика нема своје утврђено место у асоцијативном систему говорника српског језика. 


\section{Цитирана литература}

BROĆIĆ 2016: BROĆIĆ, Andrijana. „Asocijativni metod u ispitivanju konceptualizacije ponosa”. Srpski jezik, ХХІ/1 (2016): 415-435. [orig.] БРОЋИЋ, Андријана. „Асоцијативни метод у испитивању концептуализације поноса". Српски језик, XXI/1 (2016): 415-435.

DRAGIĆEVIĆ 2010a: DRAGIĆEVIĆ, Rajna. Leksikologija srpskog jezika. Beograd: Zavod za udžbenike, 2010. [orig.] ДРАГИЋЕВИЋ, Рајна. Лексикологија српског језика. Београд: Завод за уџбенике, 2010.

DRAGIĆEVIĆ 2010b: DRAGIĆEVIĆ, Rajna. Verbalne asocijacije kroz srpski jezik i kulturu. Beograd: Društvo za srpski jezik i književnost, 2010. [orig.] ДРАГИЋЕВИЋ, Рајна. Вербалне асоцијације кроз српски језик и културу. Београд: Друштво за српски језик и књижевност, 2010.

JANJIĆ 2017: JANJIĆ, Marina. „Konceptualizacija ključnih pojmova u nastavi”. Metodički horizonti - odabrana poglavlja metodike nastave srpskog jezika $i \mathrm{knji-}$ ževnosti (2017): 84-98. [orig.] ЈАЊИЋ, Марина. „Концептуализација кључних појмова у настави”. Методички хоризонти - одабрана поглавть методике наставе српског језика и кюижевности (2017): 84-98.

JANJIĆ, ČUTURA 2012: JANJIĆ, Marina i Ilijana ČUTURA. Prostor, vreme, društvo - susreti u jeziku. Jagodina: Pedagoški fakultet, 2012. [orig.] ЈАЊИЋ, Марина и Илијана ЧУТУРА. Простор, време, друштво - сусрети у језику. Јагодина: Педагошки факултет, 2012.

KEVEČEŠ 2002: KÖVECSES, Zoltán. Metaphor. A Practical Introduction. Oxford: Oxford University Press, 2002.

KLIKOVAC 2004: KLIKOVAC, Duška. Metafore u mišljenju i jeziku. Beograd: Biblioteka XX vek, 2004.

LEJKOF, DŽONSON 1980: LAKOFF, George and Mark JOHNSON. Metaphors We Live By. Chicago, London: University of Chicago Press, 1980.

MILOŠEVIĆ 2017: MILOŠEVIĆ, Ivan. „Strukturiranje pojma hotelskog poslovanja na osnovu pojmova braka i rata/ratovanja na primeru idioma u poslovnom engleskom jeziku”. Hotel link: časopis za teoriju i praksu hotelijerstva, 29-30 (2017): 124-131.

NOVOKMET 2013: NOVOKMET, Slobodan B. „Konceptualizacija pojma bol u srpskom jeziku”. Književnost i jezik, LX/3-4 (2013): 407-419. [orig.] НОВОКМЕТ, Слободан Б. „Концептуализација појма бол у српском језику”. Кюижевност и језик, LX/3-4 (2013): 407-419.

RISTIĆ 1999: RISTIĆ, Stana. „Kognitivne jedinice u strukturi koncepta reči $d u s ̌ a ~ u$ srpskom jeziku (model konceptualne analize leksičkog značenja)”. Konceptualizacija značenja reči duša u savremenom srpskom jeziku (1999): 133-144. [orig.] РИСТИЋ, Стана. „Когнитивне јединице у структури концепта речи душа у српском језику (модел концептуалне анализе лексичког значења)". Кониептуализација значена речи душа у савременом српском језику (1999): 133-144.

SLIJEPČEVIĆ 2012: SLIJEPČEVIĆ, Svetlana. „Konceptualizacija pojma savest u srp- 
skom jeziku”. Naš jezik, 43/1-2 (2012): 63-76. [orig.] СЛИЈЕПЧЕВИЋ, Светлана. „Концептуализација појма савест у српском језику”. Наш језик, 43/1-2 (2012): 63-76.

STEVANOVIĆ 2015: STEVANOVIĆ, Maja. „Pojmovne metafore tajnog gosta u oblasti restoranske kritike". Jezik, književnost, diskurs: jezička istraživanja (2015): 119-128.

VELJKOVIĆ STANKOVIĆ 2018: VELJKOVIĆ STANKOVIĆ, Dragana. „Konceptualizacija bola u srpskom jeziku”. Predavanja, 7 (2018): 159-171. [orig.] ВЕљКОВИЋ СТАНКОВИТ, Драгана. „Концептуализација бола у српском језику". Предавағьа, 7 (2018): 159-171.

\section{Извори}

RSJ 2007: Rečnik srpskoga jezika. Novi Sad: Matica srpska, 2007. [orig.] Речник српскога језика. Нови Сад: Матица српска, 2007.

SrWaC: Serbian web corpus, <http://nl.ijs.si/noske/all.cgi/corp_info?corpname=srwac>.

Đorđe Šunjevarić

\section{CONCEPTUALIZATION OF MARRIAGE CONCEPTS IN THE SERBIAN LANGUAGE}

The subject of the research is the conceptualization of concepts from the lexical-semantic field of marriage by students of the Faculty of Philosophy in Niš. The aim is to reveal the mental picture of marriage and related concepts from the perspective of young people by examining the metaphorization of isolated concepts. The associative method was used in the research. An associative test was used as a research instrument, in which excerpted examples were given as stimulus words. The results of the associative test are presented quantitatively and qualitatively. The analysis shows that in most terms, happiness, love, marriage, family and respect appear as reactions of the respondents. The dominant conceptual metaphors are: MARRIAGE IS A JOURNEY, A FAMILY HOME IS A NEST, A SPOUSE IS A SUPPORT, A RING IS A HOOP, A REGISTER IS A JUDGE, A NEW FAMILY MEMBER IS AN ANIMAL. The survey shows the conflicting attitudes of young people towards marriage, and positive reactions stand out more often.

Keywords: verbal associations, conceptualization, marriage, conceptual metaphor, Serbian language 